Maciej K. DUDEK*

\title{
Demand-Side Shocks and Macroeconomic Policy
}

\section{Introduction}

The paper delivers two novel results. It identifies a new channel, invoking micro-level uncertainty, that allows for the propagation of shocks and serves as an amplification mechanism. In addition, the paper delivers a strong result and shows that debt-financed government expenditure can be welfare improving in both the short and long terms despite its negative impact on physical capital formation.

The issues are approached in a general equilibrium setup with the assumption of imperfect competition, imperfect information, and fixed costs at the micro level. Specifically, it is assumed that economic agents, at the micro level, face individual market demand uncertainty. In particular, it is assumed the state of individual market demand can only be verified by engaging in production. The paper shows that negative aggregate demand shocks decrease expected profits and discourage economic agents from undertaking production. This leads to an endogenous suspension of the least productive units in a given period. However, the decision to suspend the least productive entities implies that the individual market demands are not observable in a given period and hence the amount of information that can be inferred about the states of the demands is reduced. As a result, economic agents in subsequent periods face greater uncertainty with regard to the state of the individual demands. Furthermore, an increase in the overall uncertainty in the economy lowers the desire of economic agents to take advantage of viable economic opportunities and in turn leads to slow recovery and persistence in output.

In a substantive sense, the paper captures a general theme that the quality of signals generated by macroeconomic variables is damaged during recessions. Therefore, recessions not only impose direct losses on the economy, but also negatively impact the informativeness of economic variables. The fact that damage inflicted by recession goes beyond output loss has been explored in other contributions. Bernanke and Gertler [1989], Gali [2001] stress the role of capital market imperfections. The authors argue that damage is done through the impact on the financial hierarchy of access to capital, popularized by Fazzari, Hubbard and Petersen [1988], which relatively tightens against smaller

\footnotetext{
* The author works at the Warsaw School of Economics' Faculty of Economics I. The paper was submitted in June 2009.
} 
businesses during recessions. Similarly, Brock and Evans [1989] show that small businesses are relatively more affected during recessions. Moreover, Greenwald and Stiglitz [1993], and Akerlof, working on the role of imperfect capital markets, adverse selection, and imperfect information, reach the conclusion that recessions can negatively influence the economy. In addition, some authors, including Bernanke and Gertler [1996], find that the composition of projects is affected during recessions. This point is also explored in this paper.

The paper shares the general view that recessions can be costly. It shows that recessions are too deep and too long. This brings on the issue of policy. In practice, the existence of recessions has routinely led to active policy measures. In particular, countercyclical debt-financed government spending remains a key policy instrument. Professional economists take an active interest in the roles of deficit and debt. Specifically, Angelatos [2002] argues that debt can serve as a device that nearly assures market completeness; Barro [1974] shows that debt can smooth distortions intertemporally; while Woodford [1990] shows that public debt can serve as private liquidity. Others, including Alesina and Tabellini [1992], and Person and Tabellini [2004], note that debt can be an outcome of political process. However, modern macroeconomics theory does not perceive public debt as a stabilization tool. This paper makes an attempt to bridge the gap between theory and policy. The paper shows that debt issues can serve as a stabilization device. In particular, the paper perceives public debt in a Keynesian mode, which means it shows that debt-financed government spending increases contemporaneous output. Moreover, contrary to conventional wisdom, the paper establishes that the impact of government debt need not lead to a fall in future potential output even though it displaces physical capital. The mechanism that makes this result feasible is a simple one. A temporary boost to demand generated by government spending leads to higher expected profits and, through the aggregate demand externality, to a higher level of output and a higher level of equilibrium profits. Increased equilibrium profits encourage entry and lead to an expansion in production. As a consequence, more market demands are observable. This leads to uncertainty resolution and enriches the informational sets. More information enables better decision making in the future and allows the economy to attain a higher level of output. Naturally, debt-financed government spending leads to a reduction in the level of investment in physical capital, which in turn implies a lower level of potential output in future periods. Obviously, the net effect depends on the relative strength of the two effects. If the effects of changes in physical capital outweigh the effects of changes of informational capital then deficits decrease welfare.

The paper is organized in seven sections. Section (2) outlines the basic model. Section (3) determines the equilibrium. Section (4) describes the process of informational capital formation. Section (5) presents sample dynamics. Section (6) discusses policy issues. The last section concludes. 


\section{Model}

The model is based on three building blocks: the OLG model of Diamond [1965], the imperfect competition paradigm of Blanchard and Kiyotaki [1987], and the assumption of incomplete information at the micro level.

\section{Agents}

There is a continuum of measure-one of agents born each period. Economic agents live for two periods. Each young agent is endowed with a unit of labor in the first period of their life. The preferences of the representative agent are represented by the following utility function:

$$
U\left(c_{1, t} c_{2, t+1}\right)=(1-\beta) \log \left(c_{1, t}\right)+\beta \log \left(c_{2, t+1}\right) .
$$

In addition, there is a continuum of measure-one of managers. The preferences of a representative manager are summarized by:

$$
U\left(c_{t}\right)= \begin{cases}c_{t}-\theta & \text { if the manager opts to engage in production } \\ c_{t} & \text { if the manager decides not to produce }\end{cases}
$$

where $c_{t}$ is the level of consumption, $\theta$ denotes a stochastic idiosyncratic shock capturing the utility costs of operating a productive unit. $\theta$ is a random variable independent cross time and cross managers drawn from a uniform distribution on interval $[\underline{\theta}, \bar{\theta}]$ and observable to the manager before he/she decides to produce or not.

\section{Goods}

There are two classes of final goods in this economy and a class of intermediate goods. There is a single final consumption good. There is a continuum of measure-one of intermediate goods, which are used as inputs in the production process of the final consumption good. In addition, there is physical capital, which plays the role of both an investment good, used as a form of saving, and a productive input.

\section{Production}

The final consumption good is produced from intermediate goods via the following CES production function:

$$
c_{t}=\left(\int_{0}^{n} c_{i, t}^{\gamma} d i\right)^{\frac{1}{\gamma}}
$$

where $c_{i, t}$ denotes the input of intermediate good $i$. The market for the consumption good is perfectly competitive. 
The intermediate goods are produced using a Cobb-Douglas technology:

$$
c_{i, t}=k_{i, t}^{\alpha} l_{i, t}^{1-\alpha}
$$

where $k_{i, t}$ denotes the amount of capital and $l_{i, t}$ denotes the amount of labor used in the process of production of good $i$. The markets for the intermediate goods are monopolistic. The demand for good i takes the form:

$$
p_{t}^{i}=D_{t}^{1-\gamma} p^{\gamma} c_{i, t}^{1-\gamma}
$$

where $D_{t}$ denotes the level of demand for the final consumption good, and $p_{t}^{i}$ and $p_{t}$ denote the price of intermediate good $\mathrm{i}$ and the consumption good respectively.

Physical capital is produced using a Cobb-Douglas technology:

$$
Q_{k}=\left(k_{t}^{c}\right)^{\alpha}\left(l_{t}^{c}\right)^{1-\alpha}
$$

out of labor and physical capital, where $l_{t}^{c}$ and $k_{t}^{c}$ denote the amount of labor and capital used in the production of physical capital. In addition, it is assumed that the market for physical capital is perfectly competitive. The input-output flow diagram is presented in Figure (1).

Figure 1. Input-Output Flow Diagram

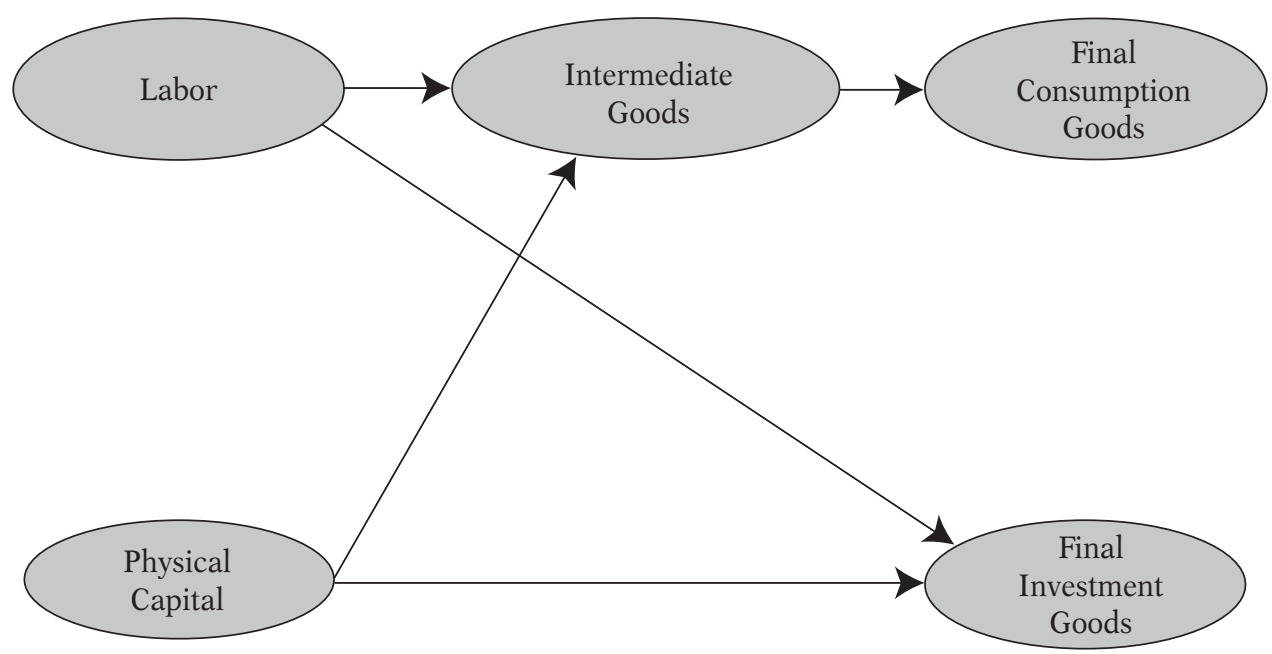

\section{Income}

There are several sources of income in this economy. First of all, factors of production receive rental fees. Second, imperfect competition in the intermediate goods sector allows profits to arise in equilibrium. Production in the intermediate goods sector is undertaken by managers. Accordingly, it 
is assumed that managers receive profits generated in the economy. Hence, their income is:

$$
y_{m, t}=\pi_{t} .
$$

The income of young agents comes from labor supply and is equal to the wage income, given by:

$$
y_{1, t}=w_{t} .
$$

The income of old agents comes from two sources. Recall that savings take the form of physical capital. Therefore, old agents can sell the capital stock that they own, the capital stock they acquired the period before, net of depreciation. In addition, they can rent out their capital and receive the return on it. Thus, old agents collect the gross return on their savings. The income of the old is given by:

$$
y_{2, t}=(1-\delta) p_{t}^{k} k_{t}+r_{t} k_{t}
$$

where $p_{t}^{k}$ denotes the equilibrium price of a unit of physical capital, $\delta$ the rate of depreciation of physical capital, $r_{t}$ the rental costs.

\section{Informational Capital}

The intermediate goods being inputs in the process of production of the final consumption good are sold on monopolistically competitive markets. Moreover, it is assumed that the demands for intermediate goods are stochastic. The value of a given demand is either positive and then depends on the fundamentals and takes the standard form given by equation (5) or is equal to zero. Furthermore, the demand for a given good that is positive in a given period remains positive in the following period with a positive probability $q$ and expires and turns to zero in the following period with a positive probability $1-q$. In other words, if $D_{t}^{i} \neq 0$, where $D_{t}^{i}$ denotes the demand for good $i$ in period $t$, then $D_{t+1}^{i} \neq 0$, with $D_{t+1}^{i}$ being the demand for good $i$ in period $t+1$, with probability equal to $q$ and $D_{t+1}^{i}=0$ with probability $1-q$. In addition, it is assumed that the demand for a good that is not coveted during a given period remains equal to zero in all future periods. The set of intermediate goods that can be potentially demanded and produced expands. Specifically, a set of new goods of measure one arrives each period. The new goods, if produced, are sold in monopolistic markets. Moreover, the probability that the demand for a given new good is positive is equal to $q^{k}$, where $k>1$ denotes a positive integer, and the probability that the demand is equal to zero is $1-q^{k}$.

Production and sales reveal the status of a given demand. An undertaking of production of a given good in a given period reveals whether the given good is coveted or not. Furthermore, if a given good is produced in a given period, and it turns out that it is not demanded, then the demand will remain equal 
to zero in all future periods and hence the good will not be produced. On the other hand, if it turns out that the demand for the good is positive, then the demand for the good in the subsequent period will be positive with probability $q$ and equal to zero with probability $1-q$. In addition, if the demand for a given good is positive with probability $q^{i}$, where $i$ is a positive integer, and the good is not produced in a given period then the demand is not observed and it remains positive in the following period with probability $q^{i+1}$. Moreover, goods of type $q^{k}$, goods demanded with probability $q^{k}$, not produced in a given period are discarded and never produced. This is due to the fact that the goods turn to type $q^{k+1}$ in the following period and it is optimal to discard them in favor of new goods of type $q^{k}$. The set of admissible types, identifying the probability that the demand for a given good is positive with the type, or the quality, of the good is given by:

$$
S=\left\{q, q^{2}, q^{3}, \ldots, q^{k}\right\} .
$$

Managers decide whether a given good is produced in a given period or not. Preferences of managers at time $t$ given by (2) and the fact that profits are the sole source of income to managers imply that the level of utility obtained by a manager who decides to produce is given by $\pi_{t}^{i} / p_{t}-\theta, \pi_{t}^{i}$ denotes the profits generated by manager $i$, and the level of utility of a manager who decides not to produce is equal to zero. Naturally, production is undertaken if the level of utility obtained from undertaking production exceeds the level of utility derived from staying idle. This defines a level of $\theta$,

$$
\theta_{c}^{i}=\frac{\pi_{t}^{i}}{p_{t}}
$$

such that a manager whose realized $\theta$ is below $\theta_{c}^{i}$ opts for production and a manager whose $\theta$ is above $\theta_{c}^{i}$ prefers not to produce.

Let $n_{t}^{i}$ denote the number of goods of type $q^{i}$, i $\varepsilon\{1,2, \ldots, k\}$, available for production in period $t$. In other words, $n_{t}^{i}$ denotes the number of markets in which the demand is non zero with probability $q^{i}$ in period $t$. Observe that managers who face a project of type $q^{i}$ and draw a favorable shock $\theta$ decide to produce and those with unfavorable shocks $\theta$ decide to stay idle. The law of large numbers implies that the number of actually operated projects of type $q^{i}$ at time $t, \eta_{t}^{i}$ is given by:

$$
\eta_{t}^{i}=\frac{\theta_{c}^{i}-\underline{\theta}}{\bar{\theta}-\underline{\theta}} .
$$

Production and sales, if undertaken, reveal fully whether a given good is demanded or not, thus allowing for perfect identification of the demand. The law of large numbers allows for the determination of the following laws of motion governing the numbers of goods of different types, the distribution of project types, in different periods: 


$$
\begin{gathered}
n_{t+1}^{1}=\sum_{i=1}^{k} q^{i}\left(1-z_{t}^{i}\right) n_{t}^{i} \\
n_{t+1}^{2}=z_{t}^{1} n_{t}^{1} \\
: \\
n_{t+1}^{k}=z_{t}^{k-1} n_{t}^{k-2} \\
n_{t+1}^{k}=z_{t}^{k-1} n_{t}^{k-1}+z_{t}^{k} n_{t}^{k}+\sum_{i=1}^{k}\left(1-q^{i}\right)\left(1-z_{t}^{i}\right) n_{t}^{i}
\end{gathered}
$$

where $z_{t}^{i}=1-\eta_{t}^{i} / n_{t}^{i}$ denotes the fraction of projects of type $q^{i}$ available for production at time $t$ that are not utilized. At any point in time the total mass of all available projects is equal to one, the mass of newly arriving projects. This is due to the fact that by assumption a single manager can at a given point in time operate at most one project and the mass of managers is equal to one.

\section{Equilibrium}

The paper approaches the problem of determination of equilibrium by analyzing the intertemporal problem first and then turning to the problem of within period allocations. It is assumed, in order to simplify the exposition, that the rate of depreciation of physical capital is equal to 1 , i.e. $\delta=1$.

\section{Consumer Problem}

The representative young agent maximizes his/her intertemporal utility subject to the budget constraints, i.e. he/she solves the following problem:

$$
\begin{gathered}
\max _{\left\{c_{1, t}, c_{2, t+1}\right.} U\left(c_{1, t}, c_{2 t+1}\right)=(1-\beta) \log \left(c_{1, t}\right)+\beta \log \left(c_{2, t+1}\right) \\
p_{t} c_{1, t}+s_{t}=y_{1, t}=w_{t} \\
p_{t}^{k} k_{t+1}=s_{t} \\
p_{t+1} c_{2, t+1}=y_{2, t+1}=r_{t+1} k_{t+1} .
\end{gathered}
$$

where $p_{t}$ and $p_{t+1}$ denote the prices of the consumption good in periods $t$ and $t+1$, and $p_{t}^{k}$ is the price of a unit of physical capital. In equilibrium each young agent saves a fraction $\beta$ income, i.e. $s_{t}=\beta y_{1, t}$. Therefore, the accumulation equation is given by:

$$
k_{t+1}=\frac{s_{t}}{p_{t}^{k}}=\beta \frac{w_{t}}{p_{t}^{k}}=\beta(1-\alpha) k_{t}^{\alpha} .
$$

Equation (13) completes the description of the intertemporal aspects of the equilibrium and is identical to the accumulation equation in the Diamond model. 


\section{Producer Problem}

There are three types of goods produced in a given period: the final consumption good, the investment good, and the intermediate goods. The final consumption good is produced using a CES technology out of intermediate goods. The market is perfectly competitive, so equilibrium profits are equal to zero and the price of the final consumption good is equal to the marginal costs, i.e.:

$$
p_{t}=\left(\int_{0}^{n}\left(p_{t}^{i}\right)^{-\frac{1}{\sigma}} d i\right)^{-\sigma}
$$

where $\sigma=(1-\gamma) / \gamma$.

The investment good is produced using a Cobb-Douglas technology and is sold on a competitive market. Therefore, equilibrium profits generated in the investment good sector are zero and the price of a unit of physical capital is equal to marginal costs. Moreover, the intermediate goods are produced using the same production function and the level of demand for a single intermediate good is given by (5) or equal to zero hence in equilibrium capital and labor are employed in the same proportion in all sectors equal to the ratio of capital to labor in the economy. Therefore, in equilibrium the price of physical capital is given by:

$$
p_{t}^{k}=\frac{w_{t}}{1-\alpha} k_{t}^{-\alpha}
$$

The market for intermediate goods is monopolistic. In equilibrium, managers decide whether to produce or not before they know whether demand for specific goods exists or not. In particular, if a given manager faces a good of type $q^{i}$ and decides to produce then the expected profits are given by:

$$
\pi_{t}^{i}=q^{i}(1-\gamma) q^{\frac{i}{\sigma}} \varphi_{t}^{-1} D_{t}+\left(1-q^{i}\right) 0
$$

where $\varphi_{t}=\sum_{j=1}^{k} \eta_{t}^{j} q^{j /(\sigma \gamma)}$ denotes the weighted average of the quality of operated projects and $D_{t}$ represents the level of the demand for the final consumption good at time $t$. Moreover, the price of the good will be equal to zero if the demand for the good does not exist and will take the form of a markup value of $1 /\left(\gamma q^{i}\right)$ over marginal costs if the demand exists. Therefore, the price of the final consumption good is given by:

$$
p_{t}=\frac{1}{\gamma} \frac{w_{t}}{1-\alpha} k_{t}^{-\alpha} .
$$

Finally, relationships (16) and (17) define the cutoff value determining the behavior of a manager who faces a project of quality $i$ as: 


$$
\theta_{c}^{i}=(1-\gamma) q^{\frac{i}{\gamma \sigma}} \varphi_{t}^{-1} d_{t}
$$

where $d_{t}=D_{t} / p_{t}$, denotes the real value of the demand for the final consumption good in period $t$.

\section{Equilibrium Demand and Output}

In equilibrium the economy generates profits in the intermediate goods sector. The level of profits generated at a given point in time in this economy can be expressed as:

$$
\pi_{t}=\left(1-{ }^{\prime}\right) D_{t}
$$

The demand for the final consumption good originates at three sources. The expenditures of the old, the managers, and the young contribute to the demand for the final consumption good. Note that both the old and the managers do not save, thus the demand for the final good at a given period is represented by:

$$
D_{t}=y_{2, t}+y_{1, t}-s_{t}+y_{m, t}=y_{2, t}+(1-\beta) y_{1, t}+y_{m, t}
$$

Furthermore, the income of the old can be written as:

$$
y_{2, t}=r_{t} k_{t}=\alpha \gamma D_{t}+\alpha D_{t}^{k}
$$

where $D_{t}^{k}=s_{t}$ denotes the demand for the investment good and the income of managers is equal to economy-wide profits given by (19).

In equilibrium the level of demand for the final consumption good in terms of the price of the final consumption good is given by:

$$
d_{t}=(1-\beta(1-\alpha)) \varphi_{t}^{\sigma} k_{t}^{\alpha}
$$

and the level of output defined as the sum of incomes of all agents in a given period in terms of the price of the final consumption good takes the form:

$$
y_{t}=(1-\beta(1-\alpha)(1-\gamma)) \varphi_{t}^{\sigma} k_{t}^{\alpha} .
$$

Both the demand for the final consumption good and the gross domestic product are decreasing functions of the marginal propensity to save $\beta$ and increasing functions of $\varphi_{t}$, i.e., increasing functions of the "average" probability that the demand for a given intermediate good produced in a given period is positive. Moreover, the model displays the multiplier effect with respect to the marginal propensity to save. A decrease in the marginal propensity to save, i.e. an increase in the level of consumption, leads to an increase in the level of profits in the intermediate goods sector; this, however, increases income 
and in turn consumption. This process ultimately culminates in an increase in the equilibrium level of income. This crucial property of the model is due to differences in the market structure for the consumption good and the investment good. The results hinge on the presence of this property. Furthermore, the level of output and the level of demand are monotone increasing with $\varphi_{t}$, a measure of the quality of operated units that is directly related to the quality of available information. Therefore, output is high when available information is rich as inputs are efficiently utilized. Similarly, output is low when there is substantial uncertainty since resources are inefficiently allocated. Naturally, both the level of demand and the level of output are increasing functions of the amount of physical capital $k_{t}$, which is itself predetermined by the decisions of consumers in preceding periods.

\section{Dynamics}

There are two forms of accumulable resources in the model: informational capital and physical capital. Physical capital is formed through a purposeful accumulation activity whereas informational capital is accumulated as a byproduct of economic activity.

The equilibrium level of demand, equation (20) and aggregate output, equation (21) in terms of the price of the final consumption good depend on resources available in the economy $\varphi_{t}, k_{t}$ and on a single parameter $\beta$ reflecting the composition of aggregate demand. This characteristic of the model allows shifts in the composition of aggregate demand to influence the contemporaneous level of output and to influence the process of formation of physical capital and informational capital and influence long-run output.

The process of formation of physical capital in this model is analogous to that in the conventional Diamond model. Savings of the current young constitute the future capital stock. The level of physical capital stock in period $t+1$, equation (13) depends only the characteristics of the technology and preferences.

The process of accumulation of informational capital is governed implicitly by the decisions of managers. Recall that managers consider undertaking projects depending on their types, the state of aggregate demand, and the idiosyncratic utility costs. In particular, projects are undertaken if the idiosyncratic utility cost is below the cutoff level. The cutoff values $\theta_{c}^{i}$ equation (18) determine the equilibrium distribution of project types. Moreover, the higher the level of demand the higher the cutoff values $\theta_{c}^{i}$ and in turn a larger number of projects are undertaken in a given period. Higher activity, with more projects operated, leads to more information revelation and allows for a faster informational capital buildup.

It turns out that $\beta$, the marginal propensity to save, is a key variable responsible for the processes of accumulation of physical capital and informational capital as well as for the magnitude of output. Naturally, the process of formation of physical capital must depend on the marginal propensity to save. However, the 
parameter $\beta$ also influences the informativeness of macroeconomic variables and is the key determinant of the informational capital stock. Recall that $\beta$ is the principal determinant of the aggregate demand. Specifically, the lower the value of $\beta$ the higher the value of the aggregate demand. In consequence, the larger the cutoff level of $\theta_{c}^{i}$ and the larger the number of projects undertaken in equilibrium. Undertaken projects reveal information regarding the status of demands. This resolves uncertainty and allows for the determination of the true type of a given project. The process leads ultimately to a higher informativeness of economic variables, larger informational capital stock and facilitates the decision-making process in future periods.

Figure 2. The Impact of a Transitory Shock to $\beta$ on Ouput

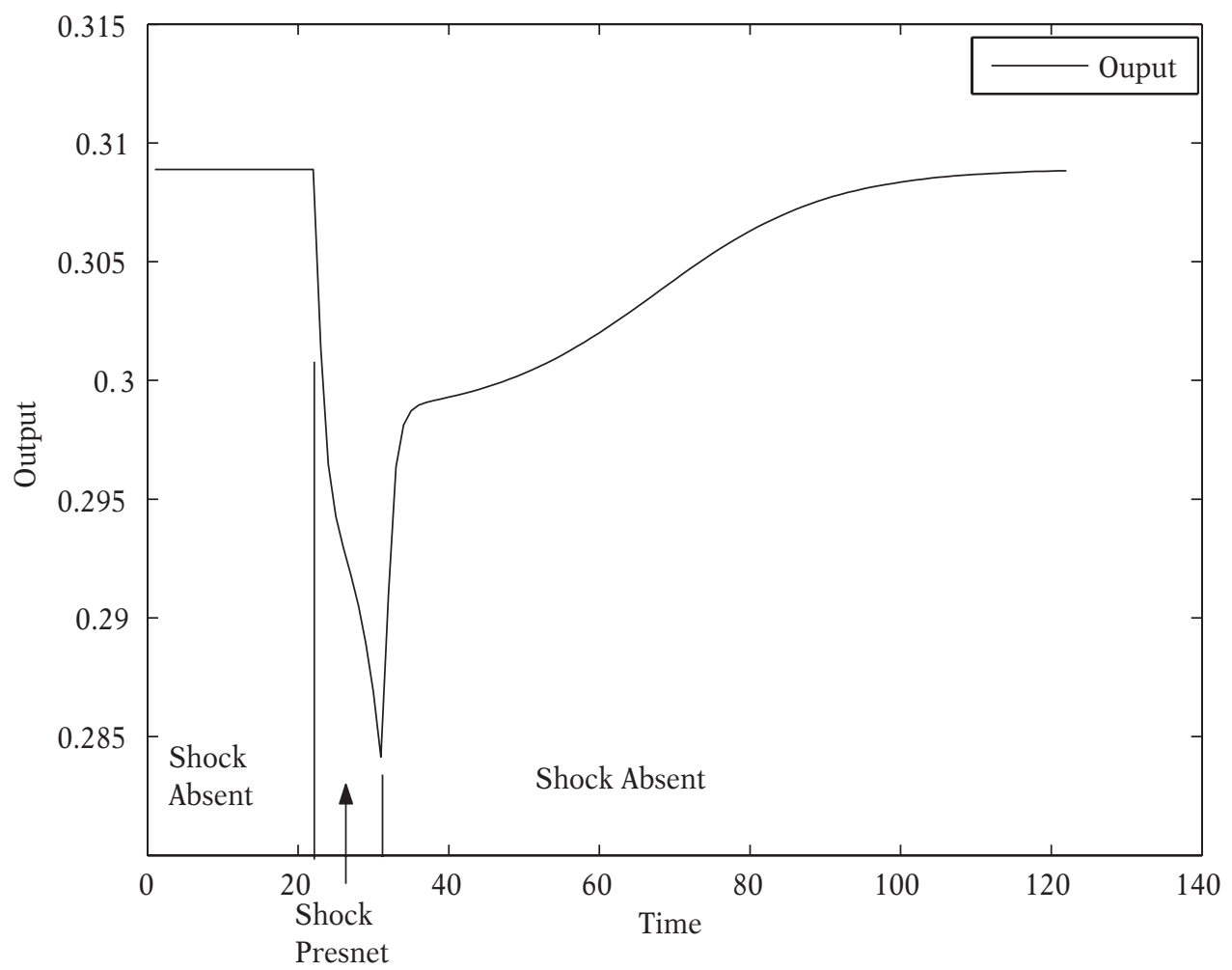

The level of informational capital and physical capital stock converge to steady-state values. Absent any changes in the fundamentals the economy remains in the steady state and only shocks can push the economy out of its longrun equilibrium. The paper focuses only on demand side shocks. Specifically, as noted earlier the marginal propensity to save $\beta$ is one of the determinants of the equilibrium level of output. Therefore, shifts in $\beta$ lead to changes in aggregate output. In particular, a rise in $\beta$ leads to an increase in the level of savings, a fall in consumption, and it turn to, through the multiplier effect, 
a fall in output. However, shifts in $\beta$ not only influence the current equilibrium values, but also influence the process of formation of both forms of capital. Specifically, a rise in the marginal propensity to save $\beta$ leads to an increase in the level of physical capital stock in future periods and to a decrease in the level of demand for the final consumption good in the current period. The fall in the demand decreases expected profits and makes entering a market less attractive. This decreases the number of operated productive units and increases the number of suspended units. Therefore, the set of observable individual market demands becomes smaller. As a result, the decisions to suspend the operation of a greater number of units exacerbate uncertainty and lead to a fall in the informational capital stock. The fall in the informational capital stock implies a lower level of output in future periods as factors of production are utilized less efficiently. Figure (2) presents sample dynamics induced by an increase in the marginal propensity to save $\beta$.

A rise in $\beta$ affects the economy both when the shock is present and when the value of $\beta$ returns to its normal value. For a given level of capital stock a rise in $\beta$ leads to a fall in output. A fall in demand, a rise in $\beta$, lowers equilibrium profits; lower profits lead to lower output; lower output leads to lower demand. The process terminates and in equilibrium the level of output is lower. Moreover, when the shock occurs the economy responds along an extensive margin. Lower expected profits lead to the suspension of a greater number of projects. Hence, the level of activity and equilibrium profits become smaller and in turn the level of output falls even more. Naturally, the reaction of the economy along the extensive margin magnifies the reaction of the economy to shocks. Moreover, in the following period there is actually more physical capital. A higher value of $\beta$ implies that agents saved more the period before. However, the level of output is smaller and keeps on falling. This is due to the fact that a fall in expected profits leads to the suspension of a greater number of projects. Therefore, there is less uncertainty resolution and the quality of projects becomes smaller in future periods. Naturally, there is more physical capital, but the information sets are of lesser quality and in equilibrium it can turn out that a higher capital stock is utilized less efficiently and the overall output falls. Finally, when the shock ceases to be present the level of output does not immediately return to its normal value. The process of recovery takes time as the level of informational capital is lower and it needs to be rebuilt before the economy can reach its pre-crisis potential. It is worth noting that during the recovery phase the level of physical capital is higher than it is in the long run and yet the destruction of informational capital stock caused by the shock to $\beta$ makes efficient usage of the physical capital stock impossible, and as a result the level of output is lower.

Summarizing, the presence of informational capital enriches the dynamics. Moreover, the presence of informational capital introduces inertia to the economy. Specifically, a negative shock to demand for consumption goods, a rise in $\beta$, leads to smaller expected profits and increases the number of suspended units. A greater number of suspended productive units inhibits 
uncertainty resolution and hampers the decision-making process in the future periods. In other words, a reduction in the level of demand leads to a fall of the informativeness of economic variables. The fall of informativeness implies less information in the future. Less information in turn implies less efficient factor usage and in turn a lower level of output. The process leads to downturns in economic activity that are too deep and too long. Alternatively, assuming that informational capital in a sense constitutes a factor of production, it can be said that the model shows that even temporary disturbances affect the potential level of output.

\section{Macroeconomic Policy}

Economic downturns are a key characteristic of rich macroeconomic dynamics. Recessions appear on average every eight years and are routinely perceived as periods of substantial welfare losses. Accordingly, policy makers implement measures designed to stimulate the economy and return the level of output to its potential. However, macroeconomic theory neither explicitly implies - albeit a recent contribution by Gali, Gertler, and Lopez-Salido [2001] indicates that sizeable welfare losses should be associated with recessions - nor it takes a clear position on the role of policy. The goal of this section is to provide a sound rationale for the shape of policy routinely implemented during recessions.

During recessions government deficits increase beyond the magnitude implied by a fall in revenues resulting from a smaller tax base. Governments attempt to stimulate the economy by directly contributing to demand, increasing government spending, or indirectly by adopting more favorable tax systems. Both approaches lead to public debt buildup. There is a rich literature that rationalizes the existence of public debt in the context of tax burden redistribution, liquidity instruments, insurance tools, or political economy. However, there is no explanation for the presence of public debt that perceives bond issues solely as a demand stimulus. Moreover, the baseline explanations suggest that deficits and debt, if non-neutral at all, can at best increase current output, but only at the expense of lower potential in the future. This paper shows that this need not be the case. It argues that deficits can have a positive impact on the economy in both the short and long run and indeed can be used as a stabilization tool to combat recessions.

The impact of public debt on equilibrium can be highlighted in the simple setup outlined below. Government spending on the consumption good in period $t$ is equal to $p_{t} G t$ and is equal to zero in all future periods. The expenditures are financed through a bond issue in period $t$ and the debt is repaid fully in period $t+1$. Taxes needed for debt repayment are levied on wage earners at time $t+1$.

Under these assumptions the level of demand and the level of output in period $t$ are given by: 


$$
\begin{gathered}
d_{t}=(1-\beta(1-\alpha)) \varphi_{t}^{\sigma} k_{t}^{\alpha}+\frac{1}{\gamma} G_{t}, \\
y_{t}=(1-\beta(1-\alpha)(1-\gamma)) \varphi_{t}^{\sigma} k_{t}^{\alpha}+\sigma G_{t} .
\end{gathered}
$$

Naturally, government expenditures contribute towards demand and towards output expressed in terms of the price of the consumption good. The result is due to the fact that spending on the consumption good increases equilibrium profits and in turn the equilibrium output. Moreover, bonds issued to finance government expenditures reduce the demand for the investment good and release resources from the investment good sector, allowing the demand for the consumption good to be met in equilibrium.

The accumulation equation, assuming that bonds are denominated in units of physical capital, takes the form identical to that in the Diamond model:

$$
k_{t+1}=\beta(1-\alpha) k_{t}^{\alpha}-b_{t+1}
$$

where $b_{t+1}$ denotes the stock of bonds issued at time $t$ and outstanding at time $t+1$. Government expenditures are fully financed through debt. Therefore,

$$
p_{t} G_{t}=p_{t}^{k} b_{t+1} .
$$

Finally, denoting the fraction of saving that takes the form of bonds by $\lambda_{t}$, the accumulation equation can be expressed as:

$$
k_{t+1}=\beta\left(1-\lambda_{t}\right)(1-\alpha) k_{t}^{\alpha} .
$$

Bond-financed government expenditures affect the level of output and demand and alter the path of investment in physical capital. Moreover, the impact is not limited to period $t$ and affects equilibrium variables in other periods via a number of channels. First of all, bonds issued at time $t$ imply that there is debt to be repaid. The repayment, by assumption, is to take place in period $t+1$ and is to be financed through taxes imposed on wage earners. Therefore, the process of repayment will amount to an effective transfer from wage earners to bond holders. However, bond holders and wage earners differ in their propensity to save. Therefore, the process of debt repayment is nonneutral for equilibrium outcomes in period $t+1$. The levels of disposable incomes of economic agents in period $t+1$ are given by:

$$
\begin{gathered}
y_{1, t}=w_{t+1}-\tau_{t+1} w_{t+1} \\
y_{2, t+1}=r_{t+1} k_{t+1}+r_{t+1} b_{t+1} \\
y_{m, t+1}=\pi_{t+1}
\end{gathered}
$$


Naturally, the government budget constraint assumes the following form:

$$
r_{t+1} b_{t+1}=\tau_{t+1} w_{t+1} .
$$

In equilibrium, the level of demand and the level of output can be expressed as:

$$
\begin{gathered}
d_{t+1}=\left(1-\beta(1-\alpha)\left(1-\tau_{t+1}\right)\right) \varphi_{t}^{\sigma} k_{t+1}^{\alpha}, \\
y_{t+1}=\left(1-\beta(1-\gamma)(1-\alpha)\left(1-\tau_{t+1}\right)\right) \varphi_{t+1}^{\sigma} k_{t+1}^{\alpha} .
\end{gathered}
$$

Obviously, both are affected by the size of government debt $\tau_{t+1}$. An effective transfer from savers to consumers increases the level of output and the level of demand. Moreover, the accumulation equation is also affected and takes the form of:

$$
k_{t+1}=\beta\left(1-\tau_{t+1}\right)(1-\alpha) k_{t+1}^{\alpha} .
$$

Finally, in equilibrium the level of taxation $\tau_{t+1}$ in period $t+1$ is related to the size of debt $\lambda_{t}$ issued at time $t$ through the following model-specific identity:

$$
\tau_{t+1}=\frac{\alpha}{1-\alpha} \frac{\lambda_{t}}{1-\lambda_{t}}
$$

In all future periods, there is no government or government debt. Therefore, the equilibrium level of demand, output, and the accumulation equation take the standard form of:

$$
\begin{gathered}
d_{t+i}=(1-\beta(1-\alpha)) \varphi_{t+i}^{\sigma} k_{t+i}^{\alpha}, \\
y_{t+i}=(1-\beta(1-\gamma)(1-\alpha)) \varphi_{t+i}^{\sigma} k_{t+i}^{\alpha}, \\
k_{t+i+1}=\beta(1-\alpha) k_{t+i}^{\alpha} .
\end{gathered}
$$

Naturally, bond-financed government expenditures affect the path of physical capital accumulation. In period $t$ the introduction of bonds crowds out physical capital. The capital stock at time $t+1$ is lower than it would be with no government presence by the amount of debt issued at time $t$. Moreover, at time $t+1$ debt repayment effectively shifts a fraction of income from savers towards consumers and as a result adversely affects the process of physical capital formation. Starting from period $t+2$ onwards, the process of physical capital accumulation is not affected. However, the process of physical capital buildup starts from a lower base and the overall trajectory of physical capital accumulation is always below the path it would take with no government intervention at time $t$. In summary, government debt introduced in period $t$ lowers the level of capital stock in all future periods. 
Government intervention at time $t$ not only influences the process of physical capital buildup, but also directly affects the equilibrium outcomes in periods $t$ and $t+1$. Bond-financed government spending contributes to the demand in period $t$ and due to the presence of aggregate demand externality increases overall output in period $t$. Similarly, taxes imposed on wage earners in period $t+1$ are transferred to old agents, the bond holders, at time $t+1$. The marginal propensity to consume is higher for the old agents than for the young agents and hence again government action at time $t+1$ contributes to an increase in demand and through the aggregate demand externality to a higher level of output. There is no direct effect in periods $t+2$ or beyond.

Moreover, government spending at time $t$ and government debt repayment at time $t+1$ influence the equilibrium indirectly. Recall that the level of aggregate demand for the consumption good constitutes a key incentive for managers to engage in productive activities. Managers follow a cutoff rule. The higher the level of deficit the higher the level of spending the higher the level of demand and the cutoff level and the more projects are undertaken. Therefore, deficit-financed government spending at time $t$ generates a higher level of demand and as a result encourages entry by managers, which further increases, through its equilibrium impact on $\varphi_{t}$, equilibrium output and equilibrium demand. Moreover, an increase in demand makes managers operate more enterprises, which reveals additional information about the actual demand for different intermediate goods. This process facilitates learning and enhances the information sets of economic agents, which means that higher demand leads to faster informational capital buildup. More information revelation at time $t$ implies a larger informational capital stock in period $t+1$. This in turn implies that decisions made at time $t+1$ will be sounder and will ultimately result in better resources allocation and a higher level of output. A similar situation takes place in period $t+1$. An effective transfer from the young to the old increases demand and in equilibrium higher profits. Higher profits encourage entry and increase the equilibrium value of $\varphi_{t+1}$, effectively leading to a higher level of output. A higher number of projects operated increases profits and in turn equilibrium output and demand. Moreover, a larger number of projects operated leads to more information revelation and faster informational capital buildup. Therefore, information sets in periods $t+2$ and beyond are richer and allow for better resource allocation and higher output. Starting from period $t+2$ there are no direct or indirect effects of government activity. Moreover, the process of informational capital formation is the same as it would be with no government presence at all. However, the stock of informational capital is higher at time $t+2$ than it would be otherwise, which implies that in all future periods it will be higher than it would be otherwise. A higher level of informational capital leads to a higher level of output.

In summary, it can be said that debt-financed government spending on the consumption good increases current output. Moreover, its impact on output in future periods depends on the relative magnitude of two competing effects. Debt decreases physical capital stock, which implies lower output in future 
periods. On the other hand, higher expected profits in the current period imply more enterprises being started up and as a consequence a higher informational capital stock in future periods. This in turn leads to better resource allocation in future periods and higher output. Naturally, if the effect pertaining to the physical capital stock dominates then debt decreases output; if the reverse is true then debt can actually increase output.

\section{Conclusions}

The paper contributes to the extensive literature on macroeconomic fluctuations. The paper is written in a very specific context, yet the results it delivers are robust. It combines several important contributions and presents new results in a unified intertemporal general equilibrium model. Specifically, the model incorporates the concepts of aggregate demand externality of Blanchard and Kiyotaki [1987], the OLG model of Diamond [1965], informational imperfections at the micro level, and nonlinearity in the form of fixed costs. The model developed in the paper is characterized by several new features. The model predicts that shifts in aggregate demand can influence economic activity in the short run while in the long run the supply side determines the equilibrium. Broadly speaking, the model constitutes an example of a unified, general equilibrium, reconciliation of the neoclassical approach with an intuitively appealing approach allowing for short-run demandside output determination.

Specifically, the paper studies in a general equilibrium framework the impact of demand-side shocks on macroeconomic variables. In particular, the paper establishes that demand-side disturbances can have persistent effects and consequently impose significant welfare losses even if their nature is transitory. The mechanism that allows transitory shocks to influence aggregate activity beyond periods when the shocks are present is due to the existence of informational imperfections. It is shown that transitory negative demand-side shocks limit uncertainty resolution when they are present, i.e. recessions are times when informational imperfections are exacerbated. As a result, economic agents face information sets of lesser quality when the shocks disappear. This leads to less efficient resource allocation and in turn to lower output.

In addition, the paper shows that government spending on the consumption good, even when it is financed through debt displacing physical capital, can increase welfare in both the short and long terms. The intuition for this result is straightforward. Debt displaces physical capital and leads to lower future output. However, increased spending increases contemporaneous output, due to the presence of aggregate demand externality, increases equilibrium profits, encourages entrepreneurial activity and leads to more uncertainty resolution as a greater number of individual market demands is identified. As a result, increased spending enhances the quality of information available to economic agents in future periods. This allows economic agents to make more informed decisions and generate higher output. The overall effect depends on the relative 
strengths of the impact on the physical capital stock and of the impact on the quality of information. Naturally, when the latter dominates the overall effect of debt-financed government spending is positive even though debt inhibits physical capital formation.

\section{References}

Acemoglu D., [March 1993], Learning About Others' Actions and the Investment Accelerator, „The Economic Journal”, pp. 318-328.

Akerlof G.E., Yellen J., [1991], How Large are the Losses from Rule of Thumb Behavior in Models of the Business Cycle?, [in:] W. Brainard, W. Nordhaus, H. Watts, eds., Money, Macroeconomics and Economic Policy: Essays in Honor of James Tobin, Cambridge, Mass: MIT Press.

Akerlof G.E., Yellen J., [September 1985], A Near Rational Model of the Business Cycle with Wage and Price Inertia, "Quarterly Journal of Economics”.

Akerlof G.E., Yellen J., [September 1985], Can Small Deviations from Rationality Make Significant Differences to Economics Equilibria?, "American Economic Review”.

Alesina A., Tabellini G., [April 1992], Positive and Normative Theories of Public Debt and Inflation in Historical Perspective, „European Economic Review Papers and Proceedings”.

Alesina A., Tabellini G., [July 1990], A Positive Theory of Fiscal Deficits and Government Debt, „Review of Economic Studies”.

Alesina A., Tabellini G., [March 1990], Voting on the Budget Deficit, „American Economic Review".

Angelatos G.-M., [August 2002], Fiscal Policy with Non-Contingent Debt and the Optimal Maturity Structure, "Quarterly Journal of Economics”, Vol. 117 (2).

Barlevy G., [January 2002], Sullying Effects of Recessions, „Review of Economic Studies”, 69(1) pp. 65-95.

Barro R.J., [Oct. 1979], On the Determination of the Public Debt, „Journal of Political Economy”, 87, 5, pp. 940-971.

Barro R.J., [Dec. 1974], Are Government Bonds Net Wealth?, „Journal of Political Economy”, 82, 6, pp. 1095-1117.

Bernanke B., Gertler M., [1989], Agency Costs, Net Worth, and Business Fluctuations, „American Economic Review" 79, pp. 14-31.

Bernanke B., Gertler M., Gilchrist S., [January 1996], The Financial Accelerator and the Flight to Quality, „The Review of Economics and Statistics”.

Bernanke B., Gertler M., Gilchrist S., [1999], The Financial Accelerator in a Quantitative Business Cycle Framework, „Handbook of Macroeconomics”, J. Taylor and M. Woodford, eds.

Blanchard O., Summers L., [1986], Hysteresis and the European Unemployment Problem, NBER Macroeconomics Annual 1, 15-78.

Blanchard O.J., [April 1985], Debt, Deficits, and Finite Horizons, „Journal of Political Economy” 93, 2, pp. 223-247.

Blanchard O.J., Kiyotaki N., [1987], Monopolistic Competition and the Effects of Aggregate Demand, „American Economic Review”, 77, pp. 647-77.

Blanchard O.-J., [May 1993], Consumption and the Recession of 1990-1991, „American Economic Review Papers and Proceedings", pp. 270-274.

Brock W.A., Evans D.S., [1989], Small Business Economics, „Small Business Economics” 1, pp. 7-20.

Caballero R.J., Hammour M., [December 1994], On Cleansing Effects of Recessions, „American Economic Review", 84(5), pp. 1350-68.

Caballero R.J., Hammour M., [August 1998], Macroeconomics of Specificity, „Journal of Political Economy", 106(4), pp. 724-76. 
Caplin A., Leahy J., [1994], Business as Usual, Market Crashes, and Wisdom After the Fact, „American Economic Review”, pp. 548-565.

Caplin A., Leahy J., [1993], Sectoral Shocks, Learning, and Aggregate Fluctuations, „Review of Economic Studies", pp. 777-794.

Diamond P.A., [December 1965], National Debt in a Neoclassical Growth Model, „American Economic Review" 55, pp. 1126-1150.

Fazzari S., Hubbard G., Petersen B.C., [1988], Financing Constraints and Corporate Investment, Brookings Papers on Economic Activity, 1988:1:141-195; reprinted in Z.J. Acs, ed., Small Firms and Economic Growth, Cheltenham, U.K.: Edward Elgar Publishing Ltd., 1995.

Gali J., Gertler M., Lopez-Salido J.D., [2001], Markups, Gaps, and the Welfare Costs of Business Fluctuations, mimeo.

Gali J., [1994], Monopolistic Competition, Business Cycles, and the Composition of Aggregate Demand, „Journal of Economic Theory”, Vol. 63, No. 1, pp. 73-96.

Gertler M., [October 1982], Imperfect Information and Wage Inertia in the Business Cycle, „Journal of Political Economy".

Greenwald B., Stiglitz J.E., [February 1993], Financial Market Imperfections and Business Cycles, „Quarterly Journal of Economics”, 108(1), pp. 77-114.

Lucas R.E. Jr., [1987], Models of Business Cycles, Oxford, Basil Blackwell.

Person T., Tabellini G., [2004], Constitutional Rules and Policy Outcomes, „American Economic Review", vol. 94, pp. 25-45.

Person T., Tabellini G., [2002], Political Economics and Public Finance, „Handbook of Public Economics", ed. by A. Auerbach and M. Feldstein, North Holland.

Rigobon R., [1997], Learning by Lending, M.I.T., Ph.D., thesis.

Shleifer A., [Dec. 1986], Implementation Cycles, „Journal of Political Economy” 94, 6, pp. 1163-1190.

Stiglitz J.E., [May 1999], Toward a General Theory of Wage and Price Rigidities and Economic Fluctuations, „American Economic Review”, 89 (2), pp. 75-80, reprinted in Market Failure or Success - The New Debate, Cowen T. and E. Crampton (eds.), Edward Elgar, 2002, pp. 1-40.

Stiglitz J.E., Weiss A., [October 1992], Asymmetric Information in Credit Markets and Its Implications for Macroeconomics, „Oxford Economic Papers”, 44(4), pp. 694-724.

Woodford M., [1990], Public Debt as Private Liquidity, „American Economic Review”, Papers and Proceedings 80 (1990), pp. 382-388.

\section{DEMAND-SIDE SHOCKS AND MACROECONOMIC POLICY}

\section{Sum mary}

The paper focuses on short-run macroeconomic dynamics triggered by demandside shocks. In particular, the paper analyzes, in a general equilibrium framework, the impact of transitory demand-side shocks on the behavior of macroeconomic variables and examines the relevance of policy instruments during downturns in economic activity. The paper establishes that transitory shocks can have persistent effects. It shows that stabilization is desirable even if shocks are transitory in nature. In particular, the article reveals that debt-financed government spending is a viable stabilization tool and can improve welfare in both the short and long terms, even though it inhibits physical capital formation.

Keywords: Business cycles, policy, debt, welfare costs. 